\title{
Tadeusz Lewaszkiewicz Język powojennych przesiedleńców z Nowogródka i okolicy Poznań 2017, ss. 512
}

Już wstępny, nawet pobieżny kontakt z książką Tadeusza Lewaszkiewicza wzbudza w czytelniku szczery podziw i uznanie dla ogromu prezentowanego materiału i niezwykłej umiejętności Autora łączenia wątków osobistych z rzetelnym, naukowym oglądem języka powojennych przesiedleńców z Nowogródka i okolicy. Tylko sama lektura spisu treści przywodzi na myśl skojarzenia z benedyktyńską pracowitością i filologiczną drobiazgowością. A że nie jest to pogląd odosobniony, wystarczy przytoczyć fragment recenzji dr hab. prof. UWr Marii Peisert, zamieszczonej na okładce:

Monografia Język powojennych przesiedleńców z Nowogródka i okolicy jest bardzo obszernym i wnoszącym wiele nowych ustaleń studium badawczym. Autor włożył w jego przygotowanie iście benedyktyński trud, który zaowocował bardzo potrzebnym i unikatowym opracowaniem, rejestrującym zjawiska językowe możliwe do opisania tylko $\mathrm{w}$ badaniach prowadzonych $\mathrm{w}$ długiej perspektywie czasowej i bliskiej relacji $\mathrm{z}$ respondentami.

Głębsza lektura książki jedynie utwierdza w przekonaniu, że mamy do czynienia z rozprawą o wysokim poziomie merytorycznym i wartości naukowej, której przecenić nie sposób. Badacz wyposażony w gruntowne narzędzia językoznawcze wyrusza w podróż sentymentalną do własnych etnicznych korzeni i w tę niezwykłą podróż krok po kroku wiedzie swego odbiorcę, dając mu dzieło niepowtarzalne i unikatowe pod względem koncepcyjnym. Uwagę zwraca bogaty materiał egzemplifikacyjny zaczerpnięty od 57 informatorów, co ważne - osób w jakiś sposób 
bliskich Autorowi: rodziców, dziadków, wujostwa, bliższego i dalszego kuzynostwa oraz przyjaciół i sąsiadów rodziny. Tadeusz Lewaszkiewicz pisze w tej kwestii tak:

Przedmiotem pracy są wybrane zagadnienia fonetyki, fleksji i składni języka powojennych przesiedleńców z okolic Nowogródka, ich dzieci urodzonych już na ziemiach zachodnich, znajomych moich rodziców oraz dwóch osób, które pozostały po wojnie w Nowogródku. Do przesiedleńców zaliczyłem również niewielką grupę emigrantów - kilka osób z rodziny nowogródzkiej w USA i Wielkiej Brytanii. [...]

Większość moich informatorów pochodzi z Grabnik, wsi znajdującej się przed drugą wojną światową dwa kilometry od Nowogródka. W latach 60. Grabniki zostały włączone do zespołu miejskiego. Niektórzy przesiedleńcy urodzili się w Nowogródku, inni we wsiach pod Nowogródkiem - w Milkiewiczach i w Bajkach (s. 11).

Książka składa się ze wstępu, pięciu rozdziałów zasadniczych, podsumowania i spisu bibliograficznego. W części wstępnej - zgodnie z praktyką stosowaną w rozprawach naukowych - zostają przedstawione przedmiot, cel i układ pracy, są omówione podstawy teoretyczno-metodologiczne rozprawy i metody badawcze, stan oraz geneza badań nad polszczyzną kresową, a także stan badań nad przeniesioną polszczyzną północnokresową i jej integracją z językiem ogólnopolskim, wreszcie istota polszczyzny kresowej dawnej i obecnej. Rozdział I poświęcony jest w całości powojennym przesiedleńcom z Nowogródka i okolicy, a w tym: sytuacji językowej i świadomości narodowej mieszkańców Nowogródka i okolicy w XIX i XX wieku, źródłom materiału językowego i metodom jego zbierania. Znajdziemy tu również wykaz informatorów wraz z życiorysami oraz pieczołowite omówienie zasad prezentowania materiału językowego, który - ze względu na swoje zróżnicowanie i chronologiczne, i formalne - może pociągać za sobą spore trudności interpretacyjno-transkrypcyjne:

Przyznaję, że miałem wątpliwości zwłaszcza z odróżnianiem $l$ przedniojęzykowo-zębowego od $t$ zredukowanego i spółgłoski bliskiej $u$ niezgłoskotwórczemu, $h$ dźwięcznego od półdźwięcznego oraz półdźwięcznego od bezdźwięcznego, $l$ miękkiego od półmiękkiego ${ }^{1}$ oraz półmiękkiego

1 T. Lewaszkiewicz podaje, że „autorzy publikacji dialektologicznych zwykle nie widzą potrzeby odróżniania $\mathrm{w}$ transkrypcji $l$ miękkiego od półmiękkiego, ponieważ takie odróżnianie często nie jest przekonujące. Stosowane oznaczenia (' lub ') dotyczą zatem zarówno $l$ miękkiego, jak i $l$ półmiękkiego" (s. 71). 
od $l$ twardego, $y$ tylnojęzykowego przed spółgłoskami tylnojęzykowymi od $n$ przedniojęzykowego przed spółgłoskami tylnojęzykowymi itd. (s. 71).

Wszelkie ujawniane wprost przez uczonego wątpliwości trzeba jednak poczytywać za - tak charakterystyczne przecież dla dojrzałych, odpowiedzialnych badawczy - solidność i rzetelność w sposobie prezentacji gromadzonego w ciągu wielu lat materiału oraz rozwagę i dobrze pojętą ostrożność w formułowaniu ostatecznych wniosków. Bez najmniejszych zastrzeżeń przyjęte przez Tadeusza Lewaszkiewicza niekonsekwentne z pozoru (ale tylko z pozoru) rozwiązania techniczne - wobec jasno wyłożonych racjonalnych argumentów - należy uznać za słuszne, logicznie i merytorycznie uzasadnione, jak choćby:

$\mathrm{W}$ takich sytuacjach stosowałem $\mathrm{w}$ transkrypcji $\ell, l^{\prime}$ oraz oznaczenie $l^{\prime}$ (jeśli dźwięk ten był trochę podobny do twardego $l$ ), $\eta$. Wprowadzałem oznaczenie spółgłosek przedniojęzykowo-dziąsłowych ț $d$ (np. țšeba, ďževo). [...]

Pewne niekonsekwencje transkrypcji wynikają również z tego, że moje zapiski pochodzą z okresu 1973-2015, a zatem te same osoby mogły różnie wymawiać te same dźwięki. [...]

Trudności $w$ transkrypcji są związane $\mathrm{z}$ licznymi wahaniami wymowy przesiedleńców, spowodowanymi przez kontakty z innymi grupami regionalnymi i wymową ogólnopolską (s. 71).

Kolejne rozdziały (II, III, IV i V) poświęcone są zagadnieniom fonetycznym (tu: wokalizmowi, konsonantyzmowi, fonetyce międzywyrazowej i akcentowi), fleksyjnym, składniowym i leksykalnym. Prezentacji materiału zawsze towarzyszy dogłębna charakterystyka zjawiska wraz z komentarzem odautorskim, odwołującym się do szerokiego tła chronologiczno-kulturowego i konfrontatywnego. To niewątpliwy walor tej pracy, monumentalnej pod względem materiałowym i poznawczym. Wieńczące pracę, dobrze skonstruowane wnioski są kolejnym już pokazem erudycyjnych, tym razem syntetyzujących umiejętności Autora.

W opisie zgromadzonego materiału dominuje metoda synchroniczna. Nierzadko jednak ma zastosowanie diachroniczne ujęcie zjawiska, a dzieje się tak wówczas, gdy konkretne zagadnienie podsystemu fonologiczno-fonetycznego, morfologicznego czy składniowego przesiedleńców z Nowogródka i członków ich rodzin jest ujmowane na tle historii języka polskiego. Jeśli chodzi o ogólne metody opisu językowego, to w rozprawie można wyróżnić metodę opisu języka mówionego oraz metodę filologiczną, polegającą na charakterystyce języka pisanego (listów, 
zeszytów szkolnych, wspomnień, podań, luźnych notatek, dokumentów). Wiele do niezaprzeczalnej wartości prezentowanej rozprawy wnosi też metoda konfrontacji językowej, polegająca na porównywaniu elementów językowych z poszczególnych podsystemów językowych w obrębie tego samego idiolektu (w różnych okresach jego istnienia/rozwoju). Chodzi też o konfrontację międzyidiolektalną, oraz o:

porównania języka/elementów języka mikrowspólnot językowych wywowdzących się z Nowogródka i okolicy, porównania języka informatorów ze stanem językowym polszczyzny północnokresowej (na podstawie literatury przedmiotu) oraz z polszczyzną ogólną (standardową) od XX w., wszelkie porównania językowe stanu $\mathrm{XX}$-wiecznej polszczyzny północnokresowej (w tym języka moich informatorów) z wcześniejszymi okresami polszczyzny kresowej i języka ogólnopolskiego, porównania z językiem białoruskim, rzadko rosyjskim, wyjątkowo litewskim (s. 14).

Konfrontacyjnymi ramami odniesienia są $\mathrm{w}$ recenzowanej rozprawie polszczyzna północnokresowa, współczesna polszczyzna standardowa, język białoruski (zwłaszcza mowa dialektalna), rzadko język rosyjski, a wyjątkowo język litewski. Dopełnienie analizy stanowią metody socjolingwistyczne, rozumiane przez Badacza szeroko. Tadeusz Lewaszkiewicz wykorzystuje bowiem narzędzia lingwistyczne służące do opisu kontaktów językowych (tj. bilingwizmu i wielojęzyczności, dyglosji, interferencji, konwergencji i dywergencji, przełączania kodów) oraz metody badania istoty idiolektów, socjolektów, wariantywności języka, kompetencji socjolingwistycznej, prestiżu językowego, zależności między kompetencją językową a wykształceniem oraz doświadczeniem społecznym, także powiązania między poczuciem narodowym a używanym na co dzień językiem.

Rozważania stricte językoznawcze wsparte są egzemplifikacją fotograficzną począwszy już od lat 20. ubiegłego wieku, fotokopiami epistolarnymi, fotokopiami dokumentów, zeszytów szkolnych, odręcznych okazjonalnych tekstów czy zapisków na odwrocie fotografii, dzięki czemu zza komentarza naukowego wyłania się żywy człowiek z ujawnioną twarzą, ujawnionym ogólnym wyglądem zewnętrznym czy ewoluującym $\mathrm{z}$ wiekiem charakterem pisma.

Jestem w pełni przekonana, że opracowanie to nie pozostanie, bo nie może pozostać bez echa. Stanowi ono bardzo cenny element w studiach nad polszczyzną kresową, ze szczególnym uwzględnieniem polszczyzny nowogródzkiej, dotąd w zasadzie niezbadanej i nieopisanej. Pewne jest 
również i to, że od tej chwili nie będzie już można wyobrazić sobie badacza, który podejmując się analizy polszczyzny opartej na substracie wschodniosłowiańskim czy litewskim, byłby zdolny pominąć w swojej bibliografii rozprawę Tadeusza Lewaszkiewicza.

Urszula Sokólska

Uniwersytet w Białymstoku 